\title{
Analysis of Contact Angle for Metallic Materials in Wastewater Pumps
}

\author{
CRISTIAN SAVIN ${ }^{1}$, CARMEN NEJ NERU ${ }^{1 *}$, CATALIN ANDREI TUGUI ${ }^{1}$, MANUELA CRISTINA PERJ U ${ }^{1,2 *}$, ANDREI VICTOR SANDU ${ }^{1,2}$, \\ COSTICA BEJINARIU ${ }^{1}$ \\ ${ }^{1}$ Gheorghe Asachi Technical University of Iasi, Faculty of Materials Science and Engineering, 67 Dimitrie Mangeron Str., 700050, \\ lasi, Romania \\ ${ }^{2}$ Centre of Excellence Geopolymer\& Green Technology (CEGeoTech), School of Materials Engineering, Universiti Malaysia \\ Perlis, Kompleks Pengajian Jejawi 2, 02600 Arau, Perlis \\ Immersed wastewater pumps work in aggressive corrosive environments and physicochemical phenomena \\ of corrosion and erosion take place at the liquid-solid interface. Due to the type of interaction between the \\ two media when the basic metallic material is hydrophobic, corrosion phenomena can occur with the \\ erosion due to the movement of the solid particles in the liquid. If the liquid is exposed to the hydrophilic base \\ material, the corrosion phenomena occur in a laminar layer, having partial protection role. In this paper, the \\ contact angle between the metals forming the pump components and the different corrosive media with \\ different composition and $\mathrm{pH}$ was measured.
}

Keywords: boundary layer, contact angle, erosion, hydrophobic, hydrophilic, surface tension

Wetting is important because it accompanies all processes that occur at gas-liquid-solid interfaces for both moving elements and static protection elements. The wetting degree is influenced by processes occurring in the liquid at: thermal treatments such as quenching in oil baths, water or salt baths; temperature variation at which the studied system operates; all moving parts that work with lubrication; transformer oil; hydroelectric pumps; wastewater or drinking water pumps; water as a cooling or heating agent [1].

It is possible to analyze: connection of the interfaces liquid-solid-gas; wetting by a certain liquid (water, oil, solutions of various concentrations and compositions) on surfaces of different nature (metal, glass, polymer, textile etc.); the influence of surface treatment on the adhesion of the liquid (thin layers deposited on metal, glass, textilespecific treatment); wetting on the same surface type with liquids of various composition (waste waters with different $\mathrm{pH}$ and compositions, various oils types and different grades of wear); paint protections; wetting on surfaces with different roughness [2].

The paper includes a study on the influence of the contact angle on the dynamic corrosion resistance of the metallic materials used in the fabrication of the immersed wastewater pumps. The contact angle (the surface tension of the liquid on a flat surface) reflects the possibility of forming a boundary layer adhering to the active surface of the pump working area [3-5]. The limit layer (where the liquid has null speed) forms a relative protection zone for both erosion and corrosion. Because the boundary layer acts favorably by increasing corrosion and erosion resistance it is important to study the possibilities of its formation by analyzing the contact angle [6-12]. At a small contact angle - the liquid adheres to the surface forming a protective layer, while at a large contact angle - the surface rejects the liquid.

\section{Experimental part}

The opportunity of the work

When a liquid flowing on a surface, besides dynamic erosion phenomena, boundary layer phenomena occurs. If the surface tension of the liquid on the metal surface is low, the liquid adheres to the surface and forms a chemically and physically stable compact film that acts as a protective film against the liquid stream moving without any erosion thatcan occur in case of turbulence or high velocity of the fluid [13].

The formed film also depends on the viscosity characteristics of the liquid, and the cohesion between the molecules of the film is high. The film is stable and relatively static or has a specific laminar behavior, not turbulent. If the surface tension of the liquid on the metal surface is high and the fluid contact angle is large, the liquid does not form a film adhering to the surface of the metal no matter what speed it is moving (even at low speeds), so that solid surfaces are exposed to both phenomena corrosion and erosion. The layer, depending on its thickness, protects the metal walls from blows caused by solid particles that move along with the stream and also protects against all types of dynamic aggressions.

Depending on the nature of the liquid (its chemical composition), corrosion phenomena may occur but will be less intense than when combined with erosion phenomena. Waste water (domestic and industrial) immersed pumps have metal components made of various types of metals - aluminum, bronze, brass, stainless steel, gray cast iron (cast iron), nodular cast iron (rotor), low alloyed steels (screws), etc.

During operation, they create the prerequisites for galvanic corrosion, because they form a galvanic series depending on the type of liquid (content in sulfur compounds, $\mathrm{pH}$, concentration of suspension elements, etc.), decomposing biological substances, bacteria, fungi, etc.

The corrosion of the elements that form the pump is also accentuated by the mechanical erosion that occurs by hitting the pump elements with sand, sludge and suspended particles (mayalso be metallic microparticles). A high influence is also the type of liquid flow - laminar or turbulent. In both cases, either physical or chemical aggression can be diminished if the liquid in which it is immersed adheres to the metal surfaces, forms a protective layer against corrosion due the suspensions [14].

Corrosion occurs also in the boundary layer but is reduced than in the absence of the boundary layer. If the contact angle between the metal parts of the pump and

\footnotetext{
* email: nejnerucarmen@yahoo.com; mcperju@tuiasi.ro
} 
the liquid (wastewater) is large, the liquid humidifies the surface to form a protective layer, and if the contact angle is low, the liquid slides over the metal and boundary layer is not formed. An influence on the surface tension represented by the angle of contact is also the thermal or thermochemical treatment of the surface.

Phosphating is the enrichment of the superficial phosphorus layer, forming stable compounds of the $\mathrm{FePO}_{4}$ (iron phosphate) type, $\mathrm{Fe}_{3}\left(\mathrm{PO}_{4}\right)_{2}, \mathrm{Zn} \mathrm{Fe}_{2}\left(\mathrm{PO}_{4}\right)_{2}, 4 \mathrm{H}_{2} \mathrm{O}^{4}$ (Phosphophilite Hydrate) $[15,16]$. The surface has a specific structure, generally porous, which leads to an increased wetting capacity of the liquids. A special influence also has the quality of the surface, implicitly roughness [17].

\section{Chemical-structural characterization of the metallic materials used}

The metallic materials which have been chosen as the basis for measuring the contact angle of the various types of wasted liquids are materials from which the components of the immersed pumps are constructed, namely: low alloyed steel, bronze, brass, aluminum alloy, lamellar graphite cast iron, nodular cast iron, phosphated nodular cast iron.

The chemical compositions of all samples were determined using a FOUNDRY-MASTER - World Wide Analytical Systems AG emission spectrophotometer. The microstructure of these alloys was analyzed by optical microscopy, according to standard procedures [18], after attack of the polished surface with a solution of $2 \%$ nitric acid in ethyl alcohol. An Optika B383 MET metallographic microscope was used.

The samples, from the above-mentioned metallic materials were prepared for metallographically evaluation being attacked with Nital $4 \%$ for ferrous materials, with ferric chloride $\left(\mathrm{FeCl}_{3}\right)$ for $\mathrm{Cu}$-alloys and weakly concentrated nitric acid $\left(\mathrm{HNO}_{3}\right)$ for aluminum alloys.

\section{Chemical analysis of support metal materials used in the} experiment

Contact angle experiments will be performed using liquid-solid angle measurement using wastewater with different $p H$ (neutral, acidic and basic) as the liquid, and as a support- the metallic materials from which the elements of immersed pumps are made, the chemical composition being shown in table 1.

Samples from the above-mentioned metallic materials were prepared metallographically and attacked with Nital $4 \%$ for ferrous materials, Cu-alloys with ferric chloride $\left(\mathrm{FeCl}_{3}\right)$ and weakly concentrated nitric acid $\left(\mathrm{HNO}_{3}\right)$ for aluminum alloys.

In figure 1 a where the microstructure of the low alloy steel sample is shown, a hypo eutectoid structure is observed, where the light portions of polygonal, equiaxial grains are ferrite $(F \alpha)$ and the dark areas are perlite (a mechanical mixture containing $88 \%$ ferrite and $12 \%$ cementite). On the lamellar graphite cast iron it is possible to distinguish the shape of the fine graphite lamellas on the background of the ferrite-perlite mass figure $1 \mathrm{~b}$.

Table 1

CHEMICAL COMPOSITION OF METALLIC MATERIALS, \%

\begin{tabular}{|c|c|c|c|c|c|c|c|c|c|c|c|c|c|}
\hline sample & $\mathrm{Fe}$ & $\mathrm{C}$ & $\mathrm{Si}$ & $\mathrm{Mn}$ & $\mathrm{P}$ & $\mathrm{S}$ & $\mathrm{Cr}$ & $\mathrm{Ni}$ & $\mathrm{Al}$ & $\mathrm{Cu}$ & $\mathrm{Ti}$ & $\mathrm{W}$ & $\mathrm{AE}$ \\
\hline $\begin{array}{c}\text { Low alloyed } \\
\text { steel }\end{array}$ & 98.5 & 0.26 & 0.11 & 0.42 & 0.02 & 0.05 & 0.09 & 0.07 & 0.02 & 0.32 & 0.02 & 0.02 & 0.1 \\
\hline sample & $\mathrm{Fe}$ & $\mathrm{C}$ & $\mathrm{Si}$ & $\mathrm{Mn}$ & $\mathrm{P}$ & $\mathrm{S}$ & $\mathrm{Cr}$ & $\mathrm{Ni}$ & $\mathrm{Ti}$ & $\mathrm{AE}$ & - & - & - \\
\hline Stainless steel & 71.5 & 0.05 & 0.45 & 1.16 & 0.03 & 0.006 & 17.1 & 9.03 & 0.55 & 0.02 & - & - & - \\
\hline sample & $\mathrm{Fe}$ & $\mathrm{C}$ & $\mathrm{Si}$ & $\mathrm{Mn}$ & $\mathrm{P}$ & $\mathrm{S}$ & $\mathrm{Cr}$ & $\mathrm{Ni}$ & $\mathrm{Cu}$ & $\mathrm{Mo}$ & $\mathrm{Sn}$ & $\mathrm{Ti}$ & $\mathrm{AE}$ \\
\hline Gray cast iron & 91.7 & 4.5 & 1.54 & 1.03 & 0.62 & 0.14 & 0.09 & 0.05 & 0.15 & 0.01 & 0.02 & 0.03 & 0.06 \\
\hline sample & $\mathrm{Fe}$ & $\mathrm{C}$ & $\mathrm{Si}$ & $\mathrm{Ni}$ & $\mathrm{Mg}$ & $\mathrm{Mn}$ & $\mathrm{P}$ & $\mathrm{S}$ & $\mathrm{Cr}$ & $\mathrm{Ti}$ & $\mathrm{Al}$ & $\mathrm{Cu}$ & $\mathrm{AE}$ \\
\hline $\begin{array}{c}\text { Nodular cast } \\
\text { iron }\end{array}$ & 92.7 & 4.50 & 2.28 & 0.12 & 0.10 & 0.09 & 0.05 & 0.04 & 0.02 & 0.02 & 0.01 & 0.01 & 0.01 \\
\hline sample & $\mathrm{Cu}$ & $\mathrm{Sn}$ & $\mathrm{Pb}$ & $\mathrm{Zn}$ & $\mathrm{Fe}$ & $\mathrm{Al}$ & $\mathrm{Ni}$ & $\mathrm{Si}$ & $\mathrm{AE}$ & - & - & - & - \\
\hline Bronze & 85.6 & 11.2 & 1.05 & 1.39 & 0.40 & 0.02 & 0.29 & 0.02 & 0.01 & - & - & - & - \\
\hline sample & $\mathrm{Cu}$ & $\mathrm{Zn}$ & $\mathrm{Al}$ & $\mathrm{Pb}$ & $\mathrm{Sn}$ & $\mathrm{Mn}$ & $\mathrm{Fe}$ & $\mathrm{Si}$ & $\mathrm{Ni}$ & $\mathrm{Co}$ & $\mathrm{Ag}$ & - & - \\
\hline Brass & 58.4 & 39.4 & 0.03 & 1.06 & 0.07 & 0.03 & 0.11 & 0.06 & 0.12 & 0.02 & 0.006 & - & - \\
\hline sample & $\mathrm{Al}$ & $\mathrm{Zn}$ & $\mathrm{Mg}$ & $\mathrm{Cu}$ & $\mathrm{Fe}$ & $\mathrm{Cr}$ & $\mathrm{Mn}$ & $\mathrm{Ti}$ & $\mathrm{V}$ & $\mathrm{Zr}$ & $\mathrm{Ga}$ & $\mathrm{Co}$ & $\mathrm{AE}$ \\
\hline Al alloy (7075) & 90.3 & 5.41 & 2.26 & 1.50 & 0.17 & 0.22 & 0.04 & 0.03 & 0.01 & 0.01 & 0.007 & 0.003 & 0.04 \\
\hline
\end{tabular}
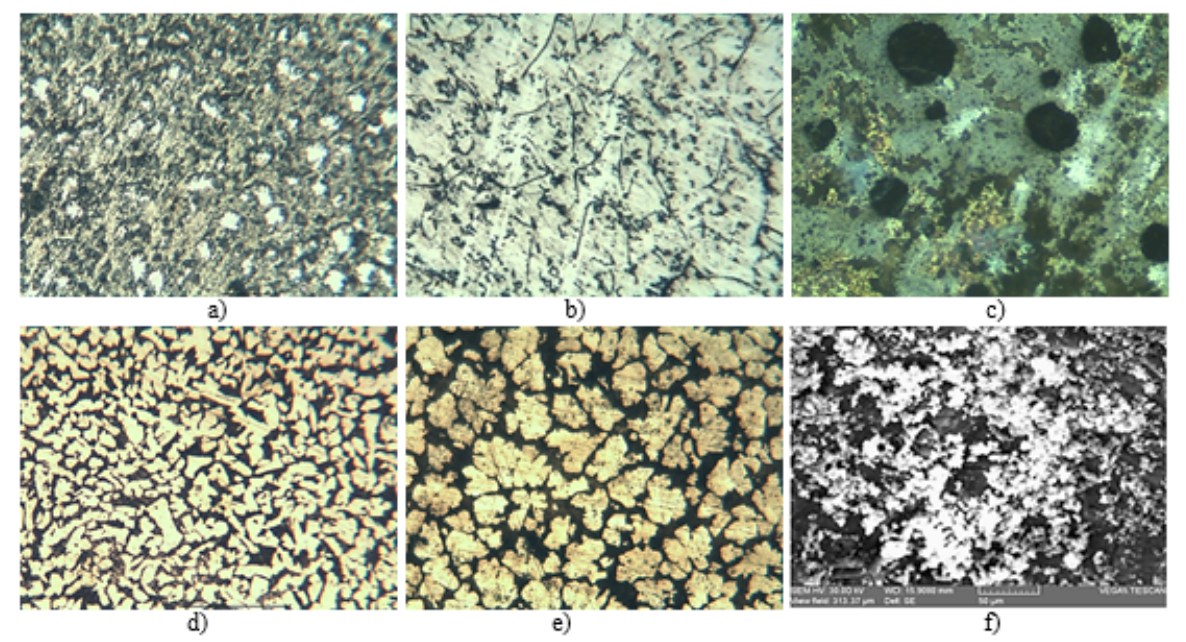

http://www.revistadechimie.ro
Fig.1. Microstructure of the samples used at various magnification powers: a) low alloyed steel sample 200x; b) gray cast iron sample with lamellar graphite 200x; c) cast iron sample with nodular graphite 200x; d) bronze sample 200x; e) 100x brass sample; f) duralumin sample $500 x$. 
Nodular cast iron is a cast iron with spheroidal graphite. Due to the nodular aspect of the graphite, the rejection effect is minimized and thus high value of strength to elongation and failure are obtained, figure $1 \mathrm{c}$. The cast bronze sample has the main Sn alloying element. It has a biphasic structure, $\alpha+\beta$, specific to castalloys, figure $1 \mathrm{~d}$. In figure 1 e a biphasic metallographic casting structure is observed. Brass containing more than $37 \% \mathrm{Zn}$ has in addition to the solid solution $\alpha$ and an intermetallic phase $\beta$. These brasses are hard and fragile and can be processed by hot plastic deformation. Thermal treatments can also be applied to obtain better technological or mechanical properties. Aluminum alloys in the Cu-Al-Mg system, also called Dural, have important mechanical strength, refractoriness and shock resistance properties and are mainly used in the naval and aeronautical industries. The structure is one of relatively small and uniform grain casting, figure $1 \mathrm{lf}$.

\section{Sample analysis of phosphated nodular iron}

The rotor of the immersed pump is heavily stressed both to erosion due to the presence of suspension microparticles in waste water as well as to corrosion due to aggressive chemical agents such as sulphides or acids.

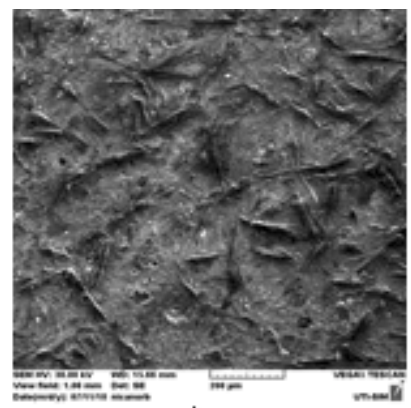

a)

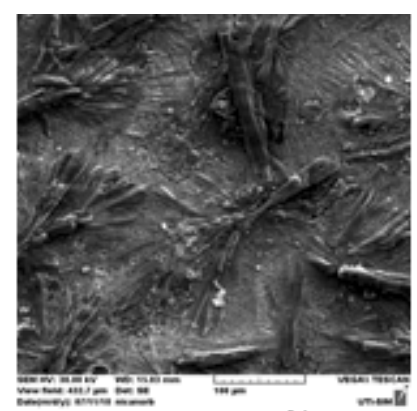

b)
Fig.2. Phosphate nodule iron microstructure: a) 200x; b) 500x.

In order to improve the surface quality of the material from which the pump rotor is made, a thermo-chemical enrichment of the surface layer with phosphate, i.e. phosphating, is carried out, obtaining the substance $\mathrm{Zn}_{2} \mathrm{Fe}\left(\mathrm{PO}_{4}\right)_{2}, 4 \mathrm{H}_{2} \mathrm{O}$ (phosphophilite hydrate) $[19,20]$.

\section{Synthetic wastewater composition}

Synthetic test waters were prepared according to the Boeije [21] studies on the average composition of sedimentary water in municipal sewage.

The composition of synthetic base waste water, called DWW-1 (Domestic Waste Water) is:

-Chemical components: $\mathrm{NH}_{4} \mathrm{Cl} 15 \mathrm{mg} / \mathrm{L}, \mathrm{CH}_{3} \mathrm{COONa}$. $3 \mathrm{H}_{2} \mathrm{O} 142 \mathrm{mg} / \mathrm{L}, \mathrm{MgSO}_{4}$. $7 \mathrm{H}_{2} \mathrm{O} 32 \mathrm{mg} / \mathrm{L}, \mathrm{CaHPO}_{4} 20 \mathrm{mg} / \mathrm{L}$, $\mathrm{K}_{2} \mathrm{HPO}_{4} \cdot 3 \mathrm{H}_{2} \mathrm{O} 56 \mathrm{mg} / \mathrm{L}$, FéSO $.7 \mathrm{H}_{2} \mathrm{O} 14 \mathrm{mg} / \mathrm{L}$, Urea 98 $\mathrm{mg} / \mathrm{L}$, Peptone $15 \mathrm{mg} / \mathrm{L}$ (Peptone - mixture of water-soluble peptides obtained by the hydrolysis of proteins under the action of pepsin).

-Food components: $118 \mathrm{mg} / \mathrm{L}$ powder, $54 \mathrm{mg} / \mathrm{L}$ brewer's yeast, $122 \mathrm{mg} / \mathrm{L}$ starch, $15 \mathrm{mg} / \mathrm{L}$ soybean oil.

-Metal artifacts: $\mathrm{Cr}\left(\mathrm{NO}_{3}\right)_{3}, 9 \mathrm{H}_{2} \mathrm{O} 0.10 \mathrm{mg}$ metal/L; $\mathrm{CuCl}_{2}$ $2 \mathrm{H}_{2} \mathrm{O} 0.20 \mathrm{mg} \mathrm{metal} / \mathrm{L}^{2}, \mathrm{MnCl}_{2} 0.05 \mathrm{mg} \mathrm{metal} / \mathrm{L}$, $\mathrm{NiSO}_{4}^{2} 7 \mathrm{H}_{2} \mathrm{O} 0.08 \mathrm{mg}$ metal $/ \mathrm{L}, \mathrm{PbCl}_{2}^{2} 0,07$.

Inorganic components are respondents for the corroded properties of the solution, while the food components behave as a corrosion inhibitor or protector. This solution has a $\mathrm{pH}$ close to neutrality: $\mathrm{pH}=6.5$.

In order to analyze the influence of $\mathrm{pH}$ on corrosion behavior, the $\mathrm{pH}$ of the basic solution (DWW-1) was modified by addition of hydrochloric acid and sodium hydroxide. Thus, alternative solutions were obtained:
DWW-2, $\mathrm{pH}=3.0$, bytitration of the basic solution with 0.1 $\mathrm{M} \mathrm{HCl}$ solution; DWW -3 , having a $\mathrm{pH}$ of 11.0 by titrating the basic solution with $0.1 \mathrm{M} \mathrm{NaOH}$ solution.

The choice and characterization of the working method consisting in measuring the angle of contact with the goniometer

The contact angle measurement gives indications of the surface tension at the solid-liquid-gas interface [22]. In the case of the immersion pump studied, the contact angle measured for each combination of metal and liquid shows corrosion and erosion possibilities with or without protective film. To carry out these measurements, a Kruss type goniometer has been used to measure the values of contact angles and superficial tension [23].

The experiments were performed in accordance with the occupational health and safety laws and regulations $[24,25]$.

\section{Results and discussions}

The contact angle provides indications of hydrophobic or hydrophilic character of a solid-liquid combination. In this case, studying the contact angle is important for characterizing the zone of the liquid medium that causes corrosion and erosion in the immersed pump. If the metal is combined with a liquid and there is a hydroscopic phenomenon, there is a tendency to form a liquid protective layer that adheres physically to the surface of the metal. The protective boundary layer is relatively stable when motion of stream is either slow or turbulent in the environment and has some elasticity that makes it remove the suspended particles moving with the liquid, decreasing the possibility of wall erosion. The protection also refers to the decrease of the corrosion intensityin the boundarylayer area, which leads to a longer operation and to keeping the working dimensions longer in functional parameters. Three types of different $p \mathrm{H}$ (neutral, acidic and basic $\mathrm{pH}$ ) waste water were used to measure the metal-liquid contact angle and distilled water for comparison. The waste water used for the measurements has been filtered with filter paper to avoid problems in the gauge, to avoid the clogging of the droplet release valve. This does not essentially influence the result because the presence of suspension particles relatively little affects the hydrophilic or hydrophobic character of the metallic material.

The results of the measurements were recorded in table 2 , based on the liquid, where the mean values and the maximum deviations were calculated.

Five measurements were made for each coupling, waste or distilled water - metal support, to see how a repeatability of the results occurs. The values in 8th column represent the average of the results obtained for the contact angle measured with the Kruss goniometer.

For all metal surfaces, apart from phosphated nodular cast iron, there are no differences greater than $10^{\circ}$, regardless of the type of droplet. One exception occurs in bronze with acidic water where a difference of $14^{\circ}$ is encountered.

Several researches have been carried due to the contact surface accuracy, which, even if was sanded and polished, can interfere with the air suspension that can influence the measurements. All surfaces, except for phosphate and bronze, are hydrophilic, both for distilled water and different wastewaters with different $\mathrm{pHs}$.

The angle of contact is between $92.1^{\circ}$ (nodular cast iron with acidic water) and $103.3^{\circ}$ (brass with distilled water), relatively close values indicating the impossibility of forming the protective film in almost all cases and the 
Table 2

RESULTS OF CONTACT ANGLE MEASUREMENTS FOR METALLIC MATERIALS AND WASTED LIQUIDS

\begin{tabular}{|c|c|c|c|c|c|c|c|}
\hline \multirow{2}{*}{$\begin{array}{l}\text { Metallic materials and } \\
\text { liquids }\end{array}$} & \multicolumn{5}{|c|}{ Contact angle measurements } & \multirow{2}{*}{$\begin{array}{c}\text { mean value } \\
\text { U.C. } \\
\text { (degree) }\end{array}$} & \multirow{2}{*}{$\begin{array}{c}\text { deviation } \\
\text { U.C. } \\
\text { (degree) }\end{array}$} \\
\hline & $\begin{array}{c}\text { U.C. } \\
\text { (degree) }\end{array}$ & $\begin{array}{c}\text { U.C. } \\
\text { (degree) }\end{array}$ & $\begin{array}{c}\text { U.C. } \\
\text { (degree) }\end{array}$ & $\begin{array}{c}\text { U.C. } \\
\text { (degree) }\end{array}$ & $\begin{array}{c}\text { U.C. } \\
\text { (degree) }\end{array}$ & & \\
\hline bronze ad & 104.1 & 105.4 & 102.9 & 97.9 & 99.8 & 102.0 & 3.1 \\
\hline low alloyed steel ad & 103.9 & 98.5 & 96.3 & 100.2 & 97.2 & 99.2 & 3.0 \\
\hline brass ad & 104.8 & 106.3 & 108.0 & 99.6 & 100.9 & 103.9 & 3.6 \\
\hline stainless steel ad & 97.9 & 96.4 & 96.2 & 98.0 & 96.5 & 97.0 & 0.9 \\
\hline aluminum ad & 99.2 & 100.0 & 101.4 & 102.2 & 102.0 & 101.0 & 1.3 \\
\hline gray cast iron ad & 96.5 & 98.0 & 98.8 & 96.5 & 98.6 & 97.7 & 1.1 \\
\hline n.c.i phosphated ad & 39.1 & 50.7 & 49.6 & 68.0 & 50.8 & 51.6 & 10.4 \\
\hline nodular cast iron ad & 101.8 & 101.5 & 101.4 & 101.1 & 104.2 & 102.0 & 1.3 \\
\hline bronze dww1 & 99.6 & 99.8 & 99.2 & 99.0 & 99.5 & 99.4 & 0.3 \\
\hline low alloyed steel dww 1 & 97.2 & 97.6 & 97.0 & 97.4 & 98.1 & 97.5 & 0.4 \\
\hline brass dww1 & 102.0 & 100.9 & 102.7 & 100.5 & 100.4 & 101.3 & 1.0 \\
\hline stainless steel dww1 & 95.3 & 94.1 & 95.3 & 95.6 & 93.0 & 94.7 & 1.1 \\
\hline aluminum dww1 & 97.6 & 99.6 & 102.1 & 98.8 & 100.7 & 99.8 & 1.7 \\
\hline gray cast iron dww1 & 96.9 & 95.5 & 93.4 & 95.6 & 94.1 & 95.1 & 1.4 \\
\hline n.c.i phosphated dww1 & 36.0 & 48.3 & 51.0 & - & - & 45.1 & 8.0 \\
\hline nodular cast iron dww1 & 99.4 & 100.3 & 99.1 & 97.2 & 94.9 & 98.2 & 2.2 \\
\hline bronze dww2 & 98.3 & 102.4 & 97.6 & 94.6 & 96.7 & 97.9 & 2.9 \\
\hline low alloyed steel dww2 & 96.8 & 97.0 & 97.1 & 98.8 & 98.0 & 97.5 & 0.8 \\
\hline brass dww2 & 101.3 & 102.0 & 100.9 & 101.6 & 100.9 & 101.3 & 0.5 \\
\hline stainless steel dww2 & 92.1 & 93.8 & 93.8 & 94.6 & 95.1 & 93.9 & 1.1 \\
\hline aluminum dww2 & 101.4 & 100.0 & 100.9 & 99.7 & 100.5 & 100.5 & 0.7 \\
\hline gray cast iron dww2 & 99.9 & 102.1 & 98.6 & 96.1 & 98.6 & 99.1 & 2.2 \\
\hline n.c.i phosphated dww2 & 65.9 & 60.8 & 44.9 & 40.4 & - & 53.0 & 12.3 \\
\hline nodular cast iron dww2 & 95.3 & 98.7 & 95.8 & 97.2 & 98.3 & 97.1 & 1.5 \\
\hline bronze dww3 & 82.8 & 88.7 & 74.7 & 80.5 & 80.6 & 81.5 & 5.0 \\
\hline low alloyed steel dww 3 & 96.8 & 94.3 & 94.8 & 94.6 & 96.6 & 95.4 & 1.2 \\
\hline brass dww3 & 99.2 & 101.6 & 100.5 & 100.5 & 98.9 & 100.1 & 1.1 \\
\hline stainless steel dww3 & 101.3 & 96.9 & 96.3 & 95.3 & 96.1 & 97.2 & 2.4 \\
\hline aluminum dww3 & 98.2 & 100.3 & 100.0 & 99.2 & 101.0 & 99.7 & 1.1 \\
\hline gray cast iron dww3 & 98.7 & 98.1 & 98.3 & 97.8 & 97.1 & 98.0 & 0.6 \\
\hline n.c.i phosphated dww3 & 68.1 & 60.9 & 61.1 & 48.4 & 38.1 & 54.4 & 11.0 \\
\hline nodular cast iron dww3 & 95.1 & 93.5 & 96.7 & 92.1 & 93.7 & 94.2 & 1.7 \\
\hline
\end{tabular}

ad - distilled water; dww - domestic waste water; U.C. - contact angle; n.c.i - nodular cast iron

occurrence of dynamic erosion and corrosion simultaneously.

At bronze with acidic water there is the possibility of a protective layer of lamellar protective film at low speeds having a contact angle of less than $90^{\circ}$ but greater than $74.7^{\circ}$. In the case of phosphated nodular iron, the contact angle shows a highly hydrophilic surface in all types of liquids with the possibility of forming the protective layer. However, there is also a strong non-uniformity in the measurement of contact angle values due to the strong porosity of the adhering layer which leads to the anchoring of the protective layer and its stability even under the high velocity of the liquid in the pump. Droplets photos (selection) are shown in figures 3 to 10.
The solid bronze surface, on which differentpH drops were used to measure the contact angle

Bronze as the base material for distilled water and waste water is a relatively hydrophobic surface, the contactangle ranging between 97.6 and $102.9^{\circ}$ (mean values) and slightly hydrophilic to acidic water with a contact angle of $80.6^{\circ}$. This shows that no protective coating is formed on the bronze plates and the erosion due to solids suspensions and particles (sand, mud, etc.) is relatively high (fig. 3).

Bronze being a material resistant to marine water (high salinity water) and wastewater, chemical corrosion is not too high (so it is not a strong destructive factor). It can be noticed that the acidic wastewater ( $\mathrm{pH}$ - 11) has a lower contact angle $\left(80.6^{\circ}\right)$ and lower surface tension, which

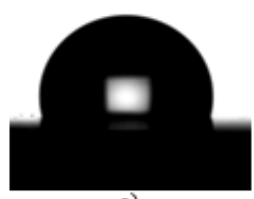

a)

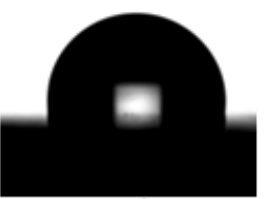

a)

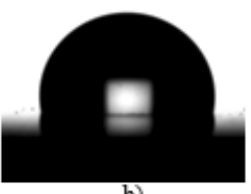

b)

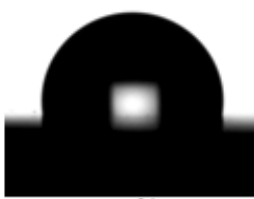

b)

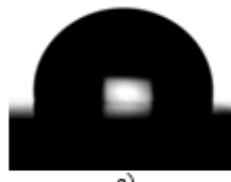

c)

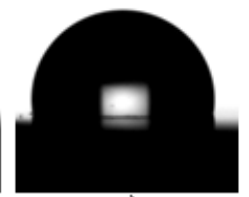

c)

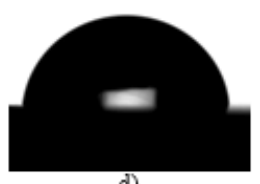

d)

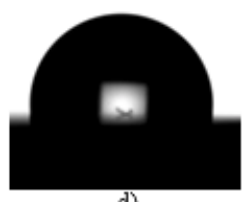

d)

Fig.3. Contact angle for bronze metal surface with: a) distilled water (contact angle: $\left.102.9^{\circ}\right)$; b) neutral $\mathrm{pH}$ (6.5) - dww1 (contact angle: $\left.99.5^{\circ}\right) ; c$ ) basic $p H$ water (3.0) - dww2 (contact angle: 97.6 ); d) wastew ater with acid pH (11.0) - dww 3 (contact angle: 80.6).

Fig.4. Contact angle for the low alloyed steel surface with: a) distilled water (contact angle: $98.5^{\circ}$ );

b) neutral pH (6.5) - dww 1 (contact angle: 97.6);

c) wastewater with basic $\mathrm{pH}$ (3.0) - dww2 (contact angle: $\left.97.1^{\circ}\right)$; d) wastewater with acid $\mathrm{pH}$ (11.0) dww 3 (contactangle: $94.8^{\circ}$ ) 


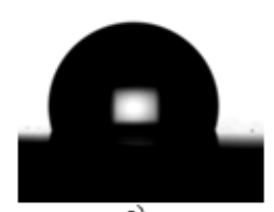

a)

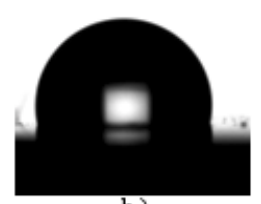

b)

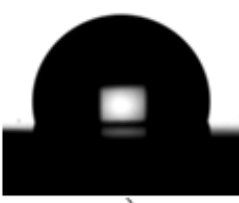

c)

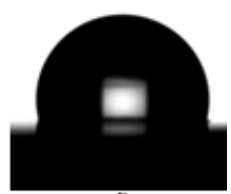

d)

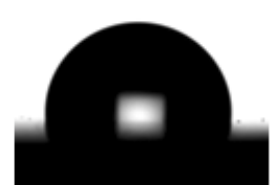

a)

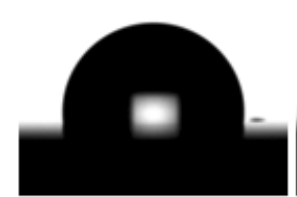

b)

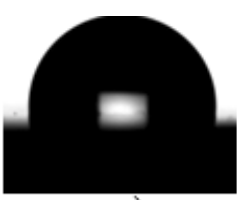

c)

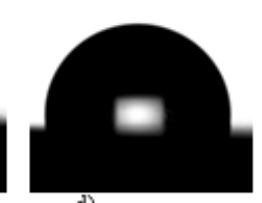

d)

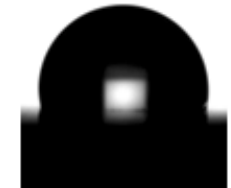

a)

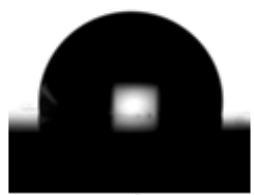

a)

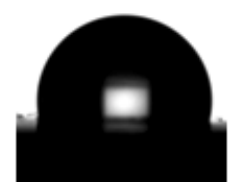

b)

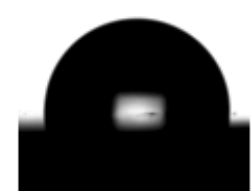

b)

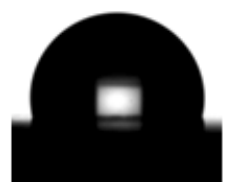

c)

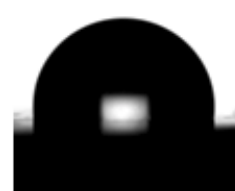

c)

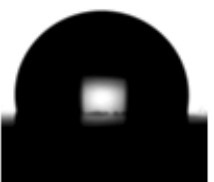

d)

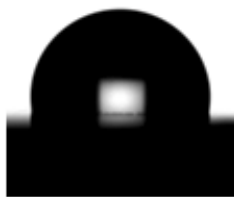

d)

Fig.5. The contact angle for the brass metal surface with: a) distilled water (contact angle: $\left.104.8^{\circ}\right)$; b) neutral $\mathrm{pH}$

(6.5) - dww1 (contact angle: $\left.100.9^{\circ}\right) ; c$ ) basic $p H$ water

(3.0) - dww2 (contact angle: $\left.101.6^{\circ}\right)$; d) wastewater with acid pH (11.0) - dww 3 (contact angle: 100.5)

Fig.6. Contact angle for stainless steel surface with: a) distilled water (contact angle: $\left.96.5^{\circ}\right) ;$ b) neutral $p H(6.5)$ dww 1 (contact angle: $\left.95.3^{\circ}\right)$; c) basic $p H$ water (3.0) dww2 (contactangle: 93.8 ); d) wastewater with acid $p H$ (11.0) - dww3 (contactangle: $96.9^{\circ}$ )

means that at low velocities of the liquid on bronze surfaces, cannot form low-thickness protection layers.

Solid surface, low-alloyed steel, with differentpH drops for measuring the contact angle

Low alloy steel has a relatively uniform, hydrophobic surface, whether distilled water or waste water, with contact angles ranging from 98.5 to $94.8^{\circ}$ (mean values) (fig. 4).

This indicates that no protective coating is formed on the surfaces, the corrosion and dynamic erosion being high and depend less on neutrality, acidity or water baseness, and more on the velocity of the stream and on the presence and size of the waste particles in the water.

The solid brass surface, which has been used to measure the contact angle, drops of wastewater with different $\mathrm{pH}$

The Cu-Zn (brass) alloy has hydrophobic characteristics for both distilled water and wastewater, with contact angles ranging from 100.5 to $104.8^{\circ}$ (mean values) (fig. 5).

It can be seen that distilled water has a slightly higher contact angle on brass compared to wastewater irrespective of $\mathrm{pH}$. This is due to the influence of homogeneous molecule corrosion compared to the heterogeneous molecules encountered in the wastewater, when dissolved in water modifies the physical and chemical characteristics of the liquid. Waste water has a very close contact angle on brass, which shows that the acidity or basicity of the waste water does not influence the adhesion of water to the surface.

Solid surface, stainless steel, which has been used to measure the contact angle, drops of wastewater with different $\mathrm{pH}$

The contact angle of distilled and wasted water on the stainless steel surface is closed as value regardless of the $\mathrm{pH}$ of the water and indicates a hydrophobic water surface(fig. 6).

A slightly lower value is for $\mathrm{pH} 3$ (basic) water on stainless steel and is 93.8 . The other values range between 95.3 $3^{\circ}$ (neutral $\mathrm{pH}$ wasted water) and $96.9^{\circ}$ (acidified $\mathrm{pH}$ wasted water). The stainless steel is resistant to corrosion in aggressive environments, but it is a soft steel, which can cause problems with microparticle erosion, because on its surface there are no protective films adhering to the surface of stainless-steel parts.

Solid surface, aluminum, on which different $\mathrm{pH}$ drops of water were used to measure the contact angle

Aluminum is a hydrophobic surface for both distilled water and wastewater irrespective of its $\mathrm{pH}$ and contact angle values varying between 99.60 (neutral $\mathrm{pH}$ water) and $101.4^{\circ}$ (distilled water) (mean values) (fig. 7).

Because the values are very close, it can be concluded that aluminum does not form protective adhering film on the surface of the parts. Aluminum and its alloys have the property of forming compactaluminum oxides with similar characteristics (water-repellent) to the surface. If the surface had been freshly ground, the absence of aluminum oxide could have given a different value for the contact angle.

The solid, lamellar gray castiron surface, on which different $\mathrm{pH}$ drops of water were applied to measure the contact angle

Gray lamellar cast iron has a hydrophobic surface for distilled water and waste water, with a contact angle varying slightly between $95.1^{\circ}$ (neutral $p H$ water) and $98.6^{\circ}$ (baseline $\mathrm{pH}$ ) (fig. 8).

Gray lamellar cast iron is usually used in the execution of the pump housing so that during operation, the mechanical and dynamic stresses are relatively low so that the lack of the protective layer does not greatly affect the reliability of the gray cast iron parts.

The solid surface, gray nodular cast iron, which has been used to measure the contact angle, drops of wastewater with different $\mathrm{pH}$

The angle of contact for water droplets on the nodular castiron support is greater than $90^{\circ}$ in all situations, ranging from $93.7^{\circ}$ (for water with $\mathrm{pH} 11$ ) and $101.8^{\circ}$ (for distilled water), (mean values) (fig. 9).

Under these conditions, the surface is hydrophilic, not allowing formation of the laminar protective layer. 


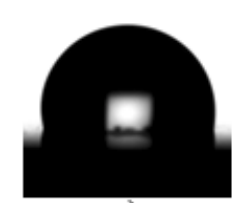

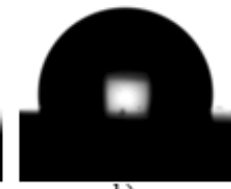

b)

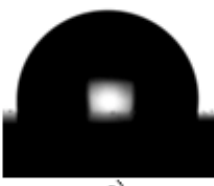

c)

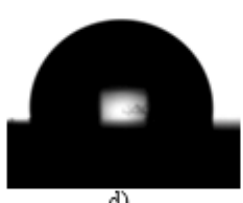

Fig.9. The contact angle for the nodular cast iron metal surface with: a) distilled water (contact angle: $\left.101.8^{\circ}\right) ;$ b) neutral $p \mathrm{H}$ (6.5) - dww1 (contact angle: 99.10); c) basic pH water (3.0) dww2 (contact angle: $\left.97.2^{\circ}\right) ; d$ ) wastewater with acid $p H(11.0)$ dww3 (contactangle: $93.7^{\circ}$ )
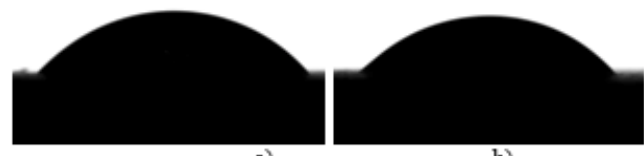

b)

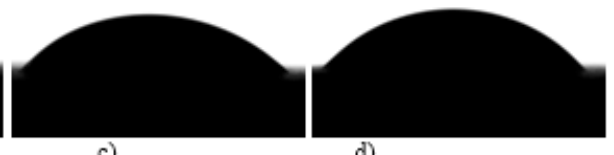

d)

Fig.10. The contact angle for the phosphorous nodular cast iron metal surface with: a) distilled water (contact angle: 50.8 ); b) neutral pH (6.5) - dww1 (contact angle: 48.30); c) basic $p H$ water (3.0) dww2 (contact angle: $44.9^{\circ}$ ) d) wastewater with acid pH (11.0) - dww3 (contact angle: 48.4\%)

Solid surface, phosphated nodular gray cast iron, to which different $\mathrm{pH}$ drops of water were used to measure the contact angle

Nodular cast iron is the material from which the rotor of the immersed wastewater pump is made and which has the purpose of gathering domestic and industrial wastewater towards treatment plant for cleaning toxic chemical elements, heavy metal particles, decomposing food waste, etc. (fig. 10)

Since the rotor is subjected to multiple dynamic aggressions (mechanical erosion) and static (chemical corrosion), a thermo-chemical phosphate treatment has been carried out on its surface, which influences both the corrosion behavior and the character of the contact angle.

The contact angle for phosphated cast iron is between $44.9^{\circ}$ for basic water and $50.8^{\circ}$ for distilled water. This indicates that the distilled water and the waste water adhere to the surface, which has a hydrophilic character, forming laminar protective coatings on the surface.

This protective layer limits erosion of rotor walls in dynamic regime, erosion due to the presence of suspension particles, metallic particles, sludge or sand. The protective effect of the lamellar layer is all the more important as the speed of use of the rotor is higher. Due to this type of deposition that is porous, the contact angle is nonuniform value, but it reflects the hydrophilic nature of the surface.

\section{Conclusions}

It is noted that the three (waste) water with acidic, basic and neutral $\mathrm{pH}$, but also distilled water react in terms of the contact angle, which is relatively similar. The contact angle has similar values for low alloyed steel or stainless steel, brass, aluminum and gray lamellar or nodular gray cast iron, the surfaces being hydrophobic. The only exception is bronze for basic $\mathrm{pH}$ water when the surface becomes hydrophilic with contact angle values between $74.7^{\circ}$ and $88.7^{\circ}$.

Thermal or thermal-chemical treatment of surfaces strongly influences the contact angle. In the studied case it is observed that the phosphated nodular iron has contact angles between 38.1 and $68.1^{\circ}$ indicating a hydrophilic surface. It is also noticed the particularly high degree of unevenness of the measured values, which indicates a roughness with high values and a high porosity of the phosphate layer.

In the case of hydrophobic surfaces (almostall the metal surfaces studied), the liquid that comes in contact with immersed pump parts hits the surfaces directly, the corrosion and the dynamic erosion occurring directly. In the case of hydrophilic surfaces, there is an adherent limiting layer on the surface of the metal to protect the erosion of suspended particles, as well as sand, grease or heavy metal micrograins that would hit the walls of the pumps. The lamellar layer on the pump walls is stationary or has a slight laminar flow compared to the dynamic turbulent flow of the liquid stream formed by dirty water. Due to this, the particles bounce on the protective layer avoiding destruction.

\section{References}

1. CHEN, L., BONACCURSO, E., GAMBARYAN-ROISMAN, T., STAROV, V., KOURSARI, N., ZHAO, Y., Static and dynamic wetting of soft substrates, Current Opinion in Colloid \& Interface Science 36, 2018, 46-57.

2. BORMASHENKO, E., Apparent contact angles for reactive wetting of smooth, rough, and heterogeneous surfaces calculated from the variational principles, Journal of Colloid and Interface Science 537, 2019, 597-603.

3. HERNANDEZ-SANDOVAL, J., GONZALEZ-LOPEZ, R., HERNANDEZRODRIGUEZ, M.A.L., GUZMÁN, A.M., Localized corrosion in an electrical submergible pump (ESP), Engineering Failure Analysis 53, 2015, 124-131.

4. SMITH P., KRAENZLER, T., Reducing effects of corrosion and erosion, World Pumps, 2017(2), 2017, 38-41.

5. ESCOBAR, J.A., ROMERO, A.F., LOBO-GUERRERO J ., Failure analysis of submersible pump system collapse caused by assembly bolt crack propagation by stress corrosion cracking, Engineering Failure Analysis 60, 2016, 1-8.

6. PARK, J., KIM, D., LEE C., Contact angle control of sessile drops on a tensioned web, Applied Surface Science 437, 2018, 329-335.

7. KARIM, A.M., ROTHSTEIN, J.P., PIROUZ KAVEHPOUR, H., Experimental study of dynamic contact angles on rough hydrophobic surfaces, J ournal of Colloid and Interface Science 513, 2018, 658-665. 8. CHEN, Y., XIA, W., XIE, G., Contact angle and induction time of air bubble on flat coal surface of different roughness, Fuel 222, 2018, 3541.

9. REMER, M., PSARSKI, M., GUMOWSKI, K., ROKICKI, J., SOBIERAJ, G., KALIUSH, M., PAWLAK, D., CELICHOWSKI, G., Dynamic water contact angle during initial phases of droplet impingement, Colloids and Surfaces A: Physicochem. Eng. Aspects 508, 2016, 57-69.

10. AMREI, M.M., DAVOUDI, M., CHASE, G.G., VAHEDI TAFRESHI, H., Effects of roughness on droplet apparent contact angles on a fiber, Separation and Purification Technology 180, 2017, 107-113.

11. GU, H., WANG, C., GONG, S., MEI, Y., LI, H., MA, W., Investigation on contact angle measurement methods and wettability transition of porous surfaces, Surface $\&$ Coatings Technology 292, 2016, 72-77.

12. WU, D., WANG, P., WU, P., YANG, Q., LIU, F., HAN, Y., XU, F., WANG $L$., Determination of contact angle of droplet on convex and concave spherical surfaces, Chemical Physics 457, 2015, 63-69.

13. ANGELA MUNTEAN, DUMITRU ION ARSENIE, Probleme generale ale mecanicii fluidelor, Editura Matrixrom, 2014.

14. SAVIN, C., NEJ NERU, C., PERJU, M.C., BEJ INARIU, C., BURDUHOSNERGIS, D., SANDU A.V., Galvanic Corrosion of Ductile Cast Iron Coupled with Different Alloys in Synthetic Domestic Waste Water, Rev. Chim.(Bucharest) 70, no. 2, 2019, p. 506-511. 
15. SANDU, A.V., BEJ INARIU, C, SANDU, I.G., ABDULLAH, M.M.A., Modern Technologies of Thin Films Deposition: Chemical Phosphatation, Materials Research Foundations, 39, 2018, 1-149.

16. SANDU, A.V., BEJ INARIU, C, SANDU, I.G., ABDULLAH, M.M.A., Thin Phosphate Film Characterization Methods and Techniques, Materials Research Foundations, 39, 2018, 54-85.

17. HEIB, F., HEMPELMANN, R., MUNIEF, W.M., INGEBRANDT, S., FUG, F., POSSART, W., GROß, K., SCHMITT, M., High-precision drop shape analysis (HPDSA) of quasistaticcontact angles on silanizedsilicon wafers with different surface topographies during inclining-plate measurements: Influence of the surface roughness on the contact line dynamics, Applied Surface Science, 342, 2015, 11-25.

18. BUEHLER SUM-MET, The Science Behind Material Preparation, A Guide to Materials Preparation and Analysis, Buehlet LTD, 2004.

19. SANDU, A.V., BEJ INARIU, C, SANDU, I.G., ABDULLAH, M.M.A., Characterization of Thin Phosphate Films, Materials Research Foundations, 39, 2018, 86-131.
20. LAZAR, P., BEJ INARIU, C., SANDU, A.V., CAZAC, A.M., CORBU, O., SANDU, I.G., PERJU, M.C., Corrosion Evaluation of Some Phosphated Thin Layers on Reinforcing Steel, IOP Conference Series-Materials Science and Engineering, 209, 2017, 012025.

21. BOEIJE, H., Chemical fate prediction for use in geo-referenced environmental exposure assessment, PhD. Thesis. Faculty of Agricultural and Applied Biological Sciences. Ghent University, p. 225, 1999.

22. YILDIRIM ERBIL, H., The debate on the dependence of apparent contact angles on drop contact area or three-phase contact line: A review, Surface Science Reports, 69(4), 2014, 325-365.

23.*** Standard Practice for Surface Wettability of Coatings, Substrates and Pigments by Advancing Contact Angle Measurement, ASTM D733408 (2013) -http://ww w.astm.org/Standards/D7334.htm.

24. BEJ INARIU, C., DARABONT, D.C., BACIU, E.R., IONITA, I., SAVA, M.A.B., BACIU, C., Considerations on the Method for Self Assessment of Safety at Work. Environ. Eng. Manag. J., 16, 2017, pp. 1395-1400. 25. BEJ INARIU, C., DARABONT, D.-C., BACIU, E.-R., GEORGESCU, I.S., BERNEVIG-SAVA, M.-A., BACIU, C., Considerations on Applying the Method for Assessing the Level of Safety at Work. Sustainability, 9, 2017, p. 1263.

Manuscript received: 9.01.2019 